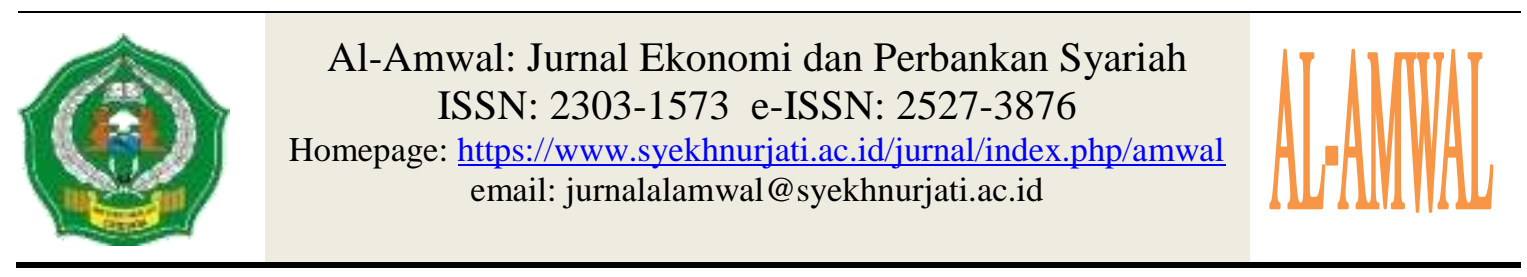

\title{
Community Based Tourism Village Planning in Kuningan Regency, West Java
}

\author{
Nining Wahyuningsih \\ IAIN Syekh Nurjati Cirebon \\ email: niningwningsih30@gmail.com \\ Diana Djuwita \\ IAIN Syekh Nurjati Cirebon \\ email: dianadjuwita12@gmail.com
}

\begin{abstract}
The purpose of this study was to determine the potential of Padabeunghar Village to establish a Community Based Tourism Village, formulate a community-based tourism village planning model in Padabeunghar Village, and assess the Kuningan District Government's efforts in forming a village-based tourism community in Padabeunghar Village. The research method used is a qualitative approach. Data collection was carried out through in-depth interviews with informants, including Dinas Pemuda, Olahraga, and Pariwisata, Dinas Lingkungan Hidup, the Padabeunghar Village Government, Kompepar, manager of Kebun Raya Kuningan, TNGC, and community representatives. The results showed that Padabeunghar Village has potential that supports village tourism planning, such as natural potential, institutional potential (local community), and the potential of local wisdom products. The Padabeunghar Tourism Village planning model involves various stakeholders, both internal and external, where each party has different roles and responsibilities and can coordinate with each other to create a sustainable tourism village. The efforts of the Kuningan regency government in community-based tourism planning are as facilitators who provide assistance, training, and empowerment to the Padabeunghar community and change their mindset so they want to develop themselves.
\end{abstract}

Keywords: Community Based Tourism, Facilitators, Tourism Planning 


\begin{abstract}
Abstrak
Tujuan penelitian ini adalah untuk mengetahui potensi apa saja yang dimiliki Desa Padabeunghar untuk pembentukan desa wisata berbasis masyarakat (Community Based Tourism), merumuskan model perencanaan desa wisata berbasis masyarakat di Desa Padabeunghar, dan untuk mengetahui upaya pemerintah Kabupaten Kuningan dalam pembentukan desa wisata berbasis masyarakat di Desa Padabeunghar.Metode penelitian yang digunakan adalah pendekatan kualitatif. Pengumpulan data dilakukan melalui wawancara mendalam dengan informan, diantaranya Dinas Pemuda, Olahraga, dan Pariwisata, Dinas Lingkungan Hidup, Pemerintah Desa Padabeunghar, Kompepar, Pengelola Kebun Raya Kuningan, TNGC dan perwakilan masyarakat. Hasil penelitian menunjukkan bahwa Desa Padabeunghar memiliki potensi-potensi yang mendukung perencanaan desa wisata seperti potensi alam, potensi kelembagaan (komunitas lokal), dan potensi produk kearifan lokal.Model perencanaan Desa Wisata Padabeunghar melibatkan berbagai stakeholders, baik internal maupun eksternal yang mana masing-masing pihak memiliki peran dan tanggung jawab yang berbeda dan dapat saling berkoordinasi untuk mewujudkan desa wisata yang berkelanjutan.Upaya pemerintah Kabupaten Kuningan dalam perencanaan desa wisata berbasis masyarakat (community based tourism) adalah sebagai fasilitator yang melakukan pendampingan, pelatihan, dan pemberdayaan masyarakat Padabeunghar serta mengubah mindset masyarakat agar mau berkembang.
\end{abstract}

Kata kunci: Community Based Tourism, Fasilitator, Perencanaan Wisata

\title{
INTRODUCTION
}

Cirebon City, Cirebon Regency, Indramayu Regency, Majalengka Regency, and Kuningan Regency (Ciayumajakuning) are the new and major economic powers in West Java after Greater Bandung. By the projection in 2028, the region will become a prestigious center of economic growth. If realized, Ciayumajakuning in 2028 will become a giant magnet for the economy, not only nationally but also in Southeast Asia. Ciayumajakuning is one of the PKN (National Activity Centers) that will become an urban area functioning to serve international, national, or several provincial-scale activities with great potential to be developed because of its abundant natural potential (fishery, agriculture, plantation, trade, services, oil, and gas), as well as strategic geographical position thus connecting access to Jakarta and Bandung as well as access to Semarang and Yogyakarta (Masruroh \& Nurhayati, 2016).

In addition, Ciayumajakuning's topography is very supportive, from waters, coasts, beaches, plains, to mountainous areas, where Cirebon Regency, Cirebon City, and Indramayu Regency are coastal areas, and Majalengka Regency and Kuningan Regency are mountainous areas. So it is not surprising that Ciayumajakuning has been used as a location for infrastructure development, especially transportation, both land, sea, and air, such as the construction of the West Java International Airport in Kertajati Majalengka, the construction of the Cipali Toll Road, the Cisumdawu Toll Road, and the Cirebon Port. The rapid development of transportation infrastructure in the Ciayumajakuning area makes Kuningan Regency, which incidentally is a mountainous area, have reliable tourism potential along with the increasing accessibility of urban 
industrial areas. So the Regency, which is famous for the natural charm of Mount Ciremai, is better known as the "peak" area of Cirebon (Masruroh \& Nurhayati, 2016).

Kuningan Regency is located in the east of West Java Province with an area of about $1,195.71 \mathrm{~km}^{2}$, which is bordered by Cirebon Regency in the north, Majalengka Regency in the west, Ciamis and Cilacap Regencies in the south, and in the east with Brebes Regency. Kuningan Regency has potential in regional tourism development, including it has a strategic geographical location, the natural charm of Mount Ciremai, a lot of tourism potential consisting of nature tourism, religious and cultural tourism, culinary tourism, and historical tourism, abundant water potential, clean and cool air (Masruroh \& Nurhayati, 2016).

This potential is supported by a government policy that stipulates Kuningan as a conservation district that always focuses on preserving the environment and natural balance, rejecting all forms of industrial development that destroy the balance of nature, so that Kuningan Regency makes tourism development one of its development priorities (Masruroh\&Nurhayati, 2016). According to the 2016 Mount Ciremai National Park Office, there are 32 objects spread across 12 sub-districts. Most of these attractions are natural, with the main attractions being water potential, valleys, and campgrounds.

Tourism, according to Law Number 10 of 2009, is a variety of tourism activities supported by various facilities and services provided by the community, businessmen, government, and local governments.Suwantoro (2005) defines tourism as a change in a person's temporary residence outside their place of residence for a reason and not for activities that generate wages. From this understanding, it can be interpreted that tourism is a journey to fulfill desires and curiosity for interests related to pleasure. According to Damanik and Weber (2006), tourism potential is an object (natural, cultural, or artificial) that requires a lot of handling in order to provide an attractive value for tourists.

Given the many problems that have been identified, as well as the need for a research focus, this research will be limited to tourism development efforts that involve the community (community-based tourism), with an emphasis on developing tourist villages. This type of tourism in Kuningan Regency has not been developed much. It is suspected that there are only three tourist villages that can be used as examples of community-based tourism development, namely Padabeunghar Village (Kuningan Botanical Garden tourism object).

Kuningan Botanical Gardens (KRK) is located in Padabeunghar Village, Pasawahan District. KRK was inaugurated in 2015 and has become one of the largest botanical gardens in Indonesia, even surpassing the size of the Bogor Botanical Gardens. As one of the tourist attractions, the existence of KRK will indirectly have an impact on improving the economy of the surrounding community. However, since it was opened, the involvement of local communities in the development of KRK is felt to be very minimal. This can be seen from the absence of a clear agreement between the KRK manager (TNGC as the owner of the area) and the village government to make Padabeunghar Village one of the tourist villages with KRK as the main tourist attraction. This study is expected to increase the acceleration of the development of tourist villages that are able to embrace all stakeholders so that they can play a strategic role in the development of tourist villages. Related parties can participate in improving the competence of local communities for local community empowerment.

Community-based development $(C B T)$ is a development model that provides the maximum opportunities for rural communities to participate in tourism development. A 
CBT is a tourism development activity carried out entirely by the community. The idea of activities and management is carried out entirely by the community in a participatory manner, and the benefits are felt directly by the local community (Sidiq\&Resnawaty, 2017). Thus, in CBT, the role of local communities as stakeholders is the most important element in the development of tourist villages. A tourism village is one form of implementing community-based and sustainable tourism development. Through the development of tourist villages, it is hoped that there will be equity in accordance with the concept of sustainable tourism development. In addition, the existence of tourist villages makes tourism products more valuable for rural culture, so that the development of tourist villages has cultural value without destroying them. Inskeep (1991) says that village tourism is a form of tourism in which a small group of tourists live in or near traditional life or in remote villages and study village life and the local environment.

Nuryanti (1992) defines a tourist village as a form of integration between attractions, accommodation, and supporting facilities that are presented in a structure of community life that is integrated with applicable procedures and traditions. It was also emphasized that the most important components in a tourist village are (1) accommodation, which is part of the residence of the local population and/or units that develop according to where the residents live, and (2) attractions, namely the entire daily life of the local population and their background. It is the physical location of the village that allows the integration of tourists as active participants in certain activities, such as dance, language, painting, and other specific courses.

In relation to the concept of tourism village development, Pearce (1995) defines tourism village development as a process that emphasizes ways to develop or advance tourist villages. More specifically, the development of tourist villages is defined as efforts to complete and improve tourism facilities to meet the needs of tourists. Local communities play an important role in the development of tourist villages because the resources and unique traditions and culture inherent in the community are the main driving elements of tourist village activities. On the other hand, local communities that grow and live side by side with a tourist attraction are part of an interconnected ecological system. The success of developing a tourist village depends on the level of acceptance and support of the local community. Local communities act as hosts and become important actors in the development of tourist villages in all stages, starting from the planning, monitoring, and implementation stages.

The purpose of this study is to find out what potential is owned by Padabeunghar Village, Pasawahan District for the formation of community-based tourism, to formulate a community-based tourism village planning model (CBT) in Padabeunghar Village, Pasawahan District, and to determine the efforts of the Kuningan Regency government in the formation of a community-based tourism village (CBT) in Padabeunghar Village, Pasawahan District.

\section{LITERATURE REVIEW}

Community empowerment (local communities) in locations that become tourist destinations through tourism business activities is one of the development models that is getting a lot of attention from various groups and will become an important agenda in tourism development in the future. Adimihardja (1999) in Sunaryo (2013: 215) defines community empowerment as a process that not only develops the economic potential of people who are powerless but also strives to increase their dignity, self-confidence, and 
self-esteem and maintains order within local cultural values. Community empowerment is interpreted as an effort to strengthen the power of or empower community groups that are powerless (powerless), usually those who are classified as marginalized communities.

Sinclair (1998) states that tourism is able to provide benefits in the form of strengthening the local economy, which includes foreign exchange, additional income for the community, and job opportunities that can be captured by the community. In tourism activities, there are several parties who have a role and are directly involved in tourism activities. The following picture illustrates the illustration of stakeholders in tourism (Sunaryo, 2013:217).

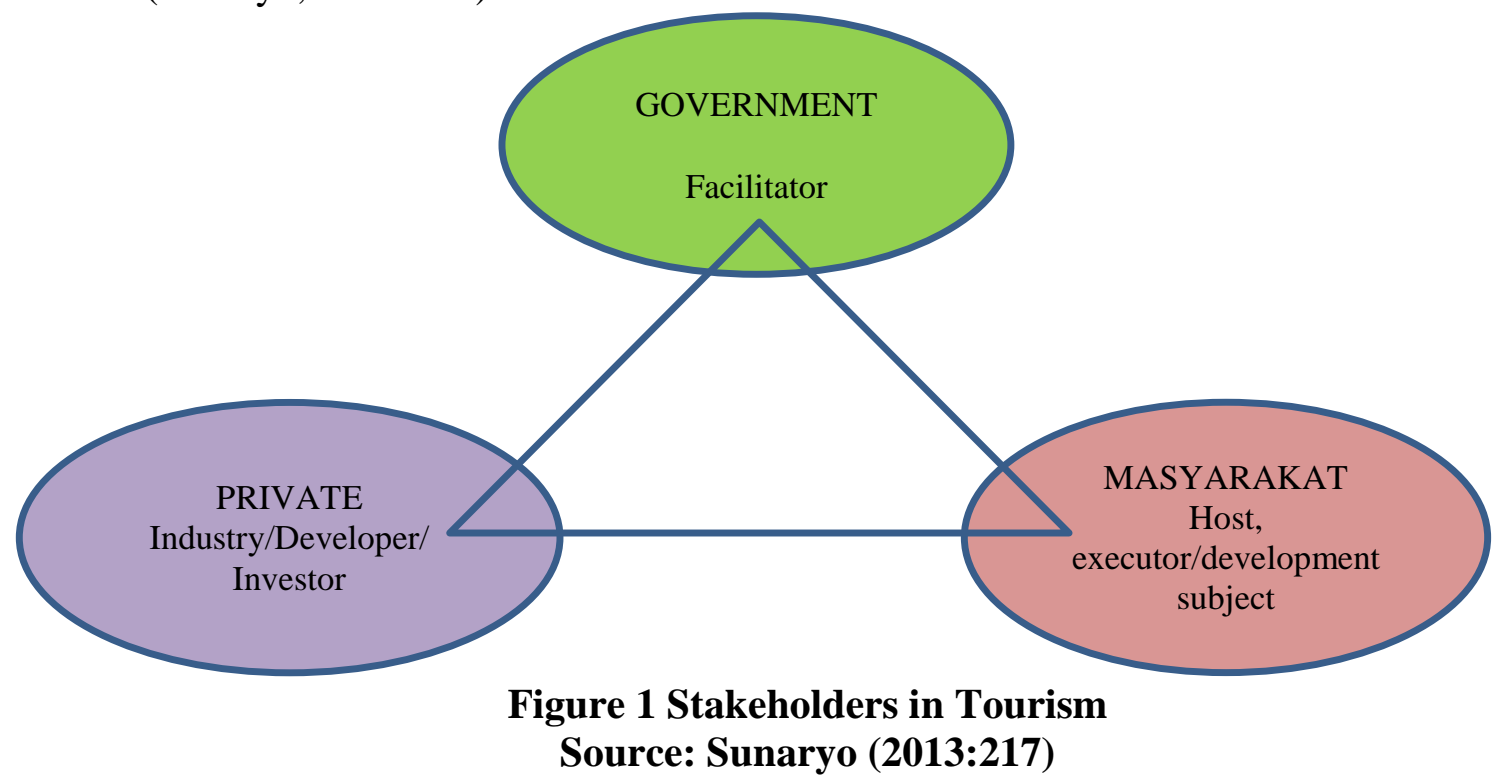

Based on the chart above, it can be concluded that the role of the community in the implementation of tourism is very large and needs to be balanced with the roles of the government and the private sector. But in reality, the role of the community is still very small when compared to the other two stakeholders. The reason is the absence or weak access they have to resources (existing tourism) and their low involvement in the decision-making process.

Murphy (1988), Larry Dawyer, Peter Forsyth, and Wayne Dwyer (2010) in Sunaryo (2013: 219), say that tourism development must be a community-based activity, with the main factor being the resources and uniqueness of the local community in the form of physical and non-physical elements. Sunaryo (2013: 218) states that in order to make tourism development run well and well managed, the most basic thing to do is to facilitate the broad involvement of local communities in the process of developing and maximizing the value of social and economic benefits from tourism activities for local communities. The local community has an equally important position as one of the stakeholders in tourism development, in addition to the government and private industry.

Based on the concept of community empowerment in tourism development, community empowerment efforts through tourism should essentially be directed at several things as follows:

1. Increasing the capacity, roles and initiatives of the tourism development community;

2. Increasing the position and quality of community involvement/participation; 
3. Increasing the value of the positive benefits of tourism development for the economic welfare of the community.

4. Increasing the community's ability to carry out tourism trips (Sunaryo (2013: 219).

Sunaryo (2013: 138) further stated that in the development of tourism that is oriented towards community empowerment, it is an issue of the current tourism development strategy. In the realm of tourism science, this strategy is known as community-based tourism (CBT). The construction of community-based tourism (community-based tourism) is in principle one of the important and critical ideas in the development of conventional tourism development theory (the growth-oriented model), which often gets a lot of criticism for ignoring rights and marginalizing local communities from tourism activities in a destination.

Suansri (2003) mentions several principles of community-based tourism that must be carried out, namely: 1) recognizing, supporting, and promoting community ownership in tourism; 2) involving community members from every stage of tourism development in its various aspects; 3) promoting pride in the community concerned; 4) improving the quality of life; 5) ensuring environmental sustainability; 6) protecting the characteristics (uniqueness) and culture of the local community; 7) developing crosscultural learning; 8) respecting cultural differences and human dignity; 9) distribute the profits and benefits obtained proportionally to members of the community; 10) contributing a certain percentage of the income earned for community development; and 11) highlighting the authenticity of the community's relationship with its environment. Based on this opinion, it can be seen that community-based tourism (CBT) is very different from tourism development in general (mass tourism).

Masruroh and Nurhayati (2016), Kuningan Regency must have superior tourist destinations, which are development priorities with consideration of the multi-flyer effect economically. The strategy that can be carried out is the government's commitment to the focus of regional tourism development, launching the concept of "city branding" as a distinctive tourism icon, increasing partnerships and interinstitutional relations in tourism management, regulatory support, and human resource development. This strategy can be developed in order to increase local revenue from the tourism sector in Kuningan Regency.

For Sidiq and Resnawaty (2017), the development of a tourist village is a planned change that requires the participation of the local community holistically. This study aims to examine community involvement in the development of tourist villages and to formulate a model for developing a tourist village that prioritizes the participation of local communities. The development of Linggarjati village, Kuningan Regency, West Java, into a tourist village has not yet involved community participation. The challenge in the process of developing a tourist village in Linggarjati is the dominance of the government in the whole process. So people do not have the opportunity and willingness to participate fully. In fact, when referring to a clean and sustainable government governance approach, the role of the government is expected to be a facilitator by providing greater roles and benefits to local communities. The government's political will is needed to reduce its role in the development of tourist villages by opening up space for the community to participate.

Prasetya and Ansar (2017) mention that strategies and approaches that can be applied in the Lake Ranau Lumbok Seminung Tourism Area with the Community Based Tourism (CBT) approach include involving the community in planning and implementing tourism activities; educating the public regarding how to interact with 
tourists; providing opportunities for the community to carry out economic activities in the Lake Ranau area; forming cultural community organizations in tourist areas; developing natural, cultural, and artificial tourism activities; and improving services to visitors; collaborating between the Tourism Office and the community in guiding tours.

\section{RESEARCH METHOD}

\section{Sources and Types of Data}

Primary data is data that can be obtained directly from the field or research site (Moleong, 2010). The research subjects were selected based on the purposive sampling technique by trying to include certain characteristics of the respondents according to the wishes of the researcher. The purpose of using this technique is to obtain clear information about the role of the Department of Culture, Tourism, Youth, and Sports in order to manage tourism potential in Kuningan Regency.

Secondary data is data obtained from reading sources and various other sources, consisting of personal letters, diaries, minutes of association meetings, and official documents from various government agencies (Moleong, 2010). The secondary data used is data from the archives of the Kuningan Regency Tourism Office.

\section{The Research Subjects}

The subjects in this study were the head of the Kuningan Regency Tourism Office, the village government, and the people of Padabeunghar Village. First, the key informant is the Head of the Kuningan Regency Tourism Office because he is the highest leader in the institution. Second, field staff, especially regarding the policies and roles of the Kuningan Regency Tourism Office. Third, the village government and tourists from the Kuningan Botanical Garden tourist attraction, as well as the people who live around the tourist attraction,

\section{Instruments and Data Collection Methods The}

Instruments used in an effort to collect data in research must pay attention to validity and reliability because good data is valid and reliable. The data collection instruments used in this research are the interview guide, observation guide, and documentation guide. The data collection methods used in this study are as follows: interviews, observations, and documentation.

\section{Data Analysis Techniques}

According to Bogdan and Biklen (Moleong, 2008), data analysis techniques are efforts made by working with data, organizing data, sorting it into manageable units, synthesizing it, looking for and finding patterns, and finding what is important and what is not. Learn and decide what to tell others. Data analysis in qualitative research includes the following stages (Milles and Huberman, 1992):

1. Data Reduction Data

Reduction is defined as the process of selecting, separating, paying attention to simplification, abstracting, and transforming rough data that emerges from written notes in the field. Data reduction takes place continuously during the research process.

2. Presentation of Data The

Presentation is done to make it easier for researchers to see the overall picture or a particular part of the research. In this study, the data is presented in the form of a brief description obtained from the results of interviews with several informants related to the implementation of cleaning service management. Apart from that, it is also presented in the form of charts and tables. 


\section{Drawing Conclusions}

Continuous verification throughout the research process, namely from the beginning of entering the research location and during the data collection process. The researcher tries to analyze and look for patterns, themes, similar relationships, things that often arise, hypotheses, and so on, which are outlined in tentative conclusions. In this study, the data validity technique used was triangulation technique, because in this study several sources of data were used from interviews and documentation.

\section{RESULT AND DISCUSSION}

\section{Profile of Padabeunghar Village, Pasawahan Kuningan}

Padabeunghar Village is located in Pasawahan District, Kuningan Regency. The total area of Padabeunghar Village is $1,632.61 \mathrm{Ha}$, which consists of $58.33 \mathrm{Ha}$ of land (settlement), 27.63 Ha of rice fields, 154.66 Ha of gardens, 21.44 Ha of village land, and Kuningan Botanical Gardens (KRK) covering an area of 166.5 hectares, Mount Ciremai National Park (TNGC) with an area of 1,268 hectares, and the remaining 3.5 hectares of plantation land, as well as office land and public facilities covering an area of 6.5 hectares. Based on the area data, it appears that the Padabeunghar Village area is dominated by TNGC, which means that most of it is a conservation area.

The population of Padabeunghar Village as of 2019 was recorded at 2,420 people, spread over three hamlets, namely Margahayu Hamlet, Margamulya Hamlet, and Margamukti Hamlet, with details as follows:

Padabeunghar Village has several rice fields irrigated, including the irrigation of Tarikolot, Lame, Lightning, Pari rice fields, Sikere, Cidulang, Paniis Kidul, Paniis Kaler, and Siseeng. In agriculture, Padabeunghar Village has Keritis Community Forest and Titisara Darat Keritis Land. There are also tourist attractions in Padabeunghar Village, including Batu Luhur (in Margamulya Hamlet), Cibujangga (in Margamulya Hamlet), Ciguntur Waterfall (in Margamukti Hamlet), and the Kuningan Botanical Gardens (in Margamulya Hamlet). In addition to irrigation and tourist attractions, Padabeunghar Village also has three lakes, namely Situ Tespon, Situ Cibuntu, and Situ Lurah.

\section{The Potential of Padabeunghar Village, Pasawahan District in Planning (Community Based Tourism Community Based Tourism)}

Padabeunghar Village, as one of the villages in Pasawahan District, has great potential to become one of the tourist villages in Kuningan Regency. Currently, the existence of Padabeunghar Village is still categorized as a tourist buffer village. The village community had received socialization on the plan to make Padabeunghar Village a tourist village.

Several potentials to support the Padabeunghar Village plan as a tourist village are grouped into 3 (three) sectors, namely (1) natural potential, (2) institutional potential (local community) and (3) potential local wisdom products. The following describes the three potentials in more detail. First, the natural potential of Padabeunghar Village consists of the Kuningan Botanical Garden (KRK), the campground (Buper), Bukit Seribu Bintang (BSB), Batu Luhur, and Batu Sepur. All of these attractions offer natural beauty, both natural and artificial, as well as the wisdom of the local community. This will certainly benefit the realization of Padabeunghar Village as a tourist village in Kuningan Regency. 
Another well-known tourist attraction in Padabeunghar is the KRK, whose management is carried out by the Regional Technical Implementation Unit (UPTD) of the Environmental Agency (BLH) of Kuningan Regency in accordance with the Kuningan Regency Regional Regulation Number 12 of 2011 concerning the Implementation of the Kuningan Botanical Gardens. In the regulation, it is mandated that the management of KRK be under the main duties of BLH.

The existence of KRK has indirectly contributed greatly and influenced Padabeunghar Village. KRK is the largest botanical garden in Indonesia with an area of 146 hectares, of which 10.3 hectares is located in the Padabeunghar Village area (www.kuningankab.go.id), which has great potential to become a leading tourist attraction in Padabeunghar Village. Before being converted into a KRK, the village community used to use the land for farming (agriculture) and gardening. After the issuance of a policy on the development of KRK, the community received compensation from the Kuningan Regency government in the form of land replacement equal to three times what they owned.

The efforts made by the Kuningan Regency government to replace community land are one of the efforts to fulfill Presidential Regulation (Perpres) No. 93 of 2011, which states that the planning for the development of a botanical garden must pay attention to the socio-cultural aspects of the community. With the high level of community interaction in the KRK area, it is necessary to find a solution that benefits both parties, one of which is the provision of valuable compensation for the converted land.

Until now, the community was still given the opportunity to continue to use the space in the KRK as a production area while still being supervised by the manager. The provision of space is an effort to involve the community in maintaining the sustainability and existence of tourism in KRK. During the KRK development process, almost 80 percent involved the people of Padabeunghar Village. This is, of course, in line with the CBT concept, although community involvement is only limited to being a workforce, not yet as a tourism driver.

In managing tourism in KRK, the village government does not get a contribution to PADes. The village government can only coordinate with the KRK manager when there is a development process that requires labor from the community or the recruitment of freelancers (THL). Actually, the village government had received information about the opportunity for PADes to contribute to tourism activities in KRK, but due to the district government's ownership of KRK, it could not be implemented.

In addition to utilizing existing tourist attractions, the village government can actually explore tourism potential in Padabeunghar. There is a lot of untapped tourism potential in Padabeunghar. For example, the potential for natural tourism in the Pasawahan area, whose scenery resembles that of Ubud, Bali, and the use of abundant water resources in Padabeunghar to serve as a base for water tourism. If it can be excavated and managed properly, then Padabeunghar will have a complete tourist attraction and can be integrated with other tours.

Second, the management of tourism in Padabeunghar Village is carried out by the local community (Karang Taruna), who form the Tourism Driving Group (KOMPEPAR). The management of tourism objects in Padabeunghar Village, except $\mathrm{KRK}$, is carried out by KOMPEPAR in collaboration with the private sector. At least three (3) KOMPEPARs drive tourism in Padabeunghar Village, namely, the Pujangga Manik group, managing the Batu Luhur tourist attraction; the Batu Sepur group, which 
manages the Batu Sepur and Bukit Seribu Bintang tourism objects; and the Jaya Pakuan group, which manages the Japanese Garden,

The existing three KOMPEPAR Gardens in Padabeunghar Village are not registered and are officially registered at the Kuningan Regency Youth, Sports, and Tourism Office (DISPORAPAR). This means that the youth groups who drive tourism in Padabeunghar Village have not yet received technical guidance related to superior and competitive tourism management. This was agreed upon by DISPORAPAR, who stated that KOMPEPAR in Padabeunghar Village had not registered (registration) so that education on good tourism management could not be given.

Opportunities to develop tourism potential in Padabeunghar are wide open because the Gunung Ciremai National Park Office (BTNGC), as the owner of the area whose territory coincides with village land, provides many opportunities for KOMPEPAR and the village government to take advantage of environmental services in the BTNGC area. Together with the village government, KOMPEPAR can create a cooperative as a joint venture. The existence of a cooperative will make it easier for stakeholders to provide guidance and education related to the management of environmental services (tourism) in the BTNGC area.

The large tourism potential in Padabeunghar Village has actually attracted the interest of the urban population. The increasing desire of the people of Padabeunghar Village who want to return to the village and develop its tourism potential has certainly become a major capital for the implementation of community-based tourism and has become additional energy in planning village tourism efforts. Contributions that can be given include capital, marketing strategies, and technology transfer for MSMEs in the village.

Third, the existence of local wisdom products supports tourism. It must be admitted that the people of Padabeunghar Village do not fully understand the existence of tourism in the village area as a business opportunity. Whereas the existence of tourism potential will have an impact on the economic value of the community. According to Sinclair (1998), tourism is able to provide benefits in the form of strengthening the local economy, including additional income to the community and job opportunities that can be captured by the community. The average village community prefers to be workers at tourist sites rather than participate in developing tourism. In fact, if examined further, the tourism carrying capacity of the people of Padabeunghar Village is very potential, such as the existence of MSME products, both processed and handicrafts, that can be marketed at tourist attractions. Until now, these products are still minimally marketed around tourist attractions.

Local wisdom products produced by the Padabeunghar community can actually be a tourist driver and have an advantage over other tourist attractions. According to Murphy (1998), Dawyer, Forsth, and Dwyer (2010) in Sunaryo (2013:19), stated that tourism development must be a community-based activity. With the main factor being the uniqueness and resources of the local community, both in the form of physical and non-physical elements (traditions and culture) attached to the community, it must be the main driving force in tourism.

Strengthening existing products needs to be improved in terms of innovation and technology. Community products need to be given a touch of innovation, especially when Padabeunghar Village is designated as a tourist village. The public needs to be educated not only about how to make, but also how to present products that are in accordance with tourism service standards. This is important because, according to 
Ryenaldy's (2014) research, the potential for community involvement in tourism management is very high at $93 \%$, and the remaining $7 \%$ stated that they did not want to be involved. It's just that the potential for community involvement is dominated by the desire to become workers or trade around KRK. Meanwhile, their involvement as actors in driving tourism was not found. Community involvement will not only produce products (food, drinks, and accessories) but also help people understand how to present tourism-standard products.

The practice of people who have knowledge of how to present local products is part of tourism governance, where the community controls and plays an active role in the management and development of existing tourism. This means that people act as actors, not as objects of tourism activities (become players, not spectators). There are several factors that cause the low involvement of the community in the development of tourist villages in Kuningan Regency, namely: (1) the idea of a tourist village does not come entirely from the community, but from the Kuningan Regency government; and (2) as a result of the situation in point (1), the local community is only the implementer of government programs such as receiving guests and handing over land to build tourist facilities. Communities are not involved as "players" in tourism activities; and (3) the local community or community does not have the opportunity and power to participate in decisions to be taken in the management of community-based tourism. Gunn and Var (2002) also argue that if local communities are not involved in the planning process, there will be malfunctions and inefficiencies in tourism development.

In addition to having great potential for planning to become a tourist village, there are obstacles that hinder the conversion process of Padabeunghar Village into a tourist village, namely the lack of communication between KOMPEPAR and the village. The village government is not involved in the process of establishing a tourist attraction, even though the object is included in the Padabeunghar Village area. The village government only gets notifications about the establishment of tourist attractions from youth groups. The developers (private) and groups only propose the establishment of a tourist attraction for BTNGC as the owner of the area and tend to ignore that the location of the tourist attraction is in the Padabeunghar Village area.

Problems related to licensing and the establishment of tourist objects have been discussed and consultations with BTNGC. The BTNGC only gave presentations related to tourism management that intersects with conservation areas.

It was also acknowledged by the village government that the unstable condition of the village government due to the absence of a definitive village head made the bargaining position of the village government very weak. The current administration is carried out by the Temporary Official (Pjs) of the Village Head, whose authority is very limited, including in the preparation of regulations. Until now, the village government did not have a village regulation (Perdes) that regulates tourism activities in Padabeunghar Village. This condition results in the loss of potential village original income (PADes) from the tourism sector.

The Padabeunghar Village Government has the desire that the tourism sector contribute to PADes such as tourism management in Paniis Village. It is just that the village government needs to understand that there is a real difference between the management of tourism in Paniis Village and the implementation of tourism in Padabeunghar Village. The implementation of tourism in Paniis Village is managed by a regional-owned enterprise in Kuningan Regency named the Regional Enterprises Company (PDAU), where PDAU provides profit sharing for the implementation of 
tourism in Paniis Village. Meanwhile, tourism in Padabeunghar Village is generally managed by the private sector, where there is no real contribution to PADes and only provides job opportunities for residents of the Padabeunghar community.

Based on the description above, the Padabeunghar tourism village planning approach requires the participation of various decision makers in the tourism planning process so that the community is able to identify the various impacts of tourism and then formulate strategies and programs to optimize the positive impacts and minimize the negative impacts caused by the development of tourism destinations.

\section{Community-Based Tourism Village Planning (CBT) in Padabeunghar Village, Pasawahan Subdistrict}

Development to become a tourism village requires the cooperation and participation of all village communities and requires good planning, so that it can attract for tourists (Permanasari, 2010).

The principle of implementing good tourism governance is the coordination and synchronization of programs between stakeholders as well as active participation that is synergistic and mutually reinforcing between the parties concerned (Sunaryo, 2013).

The tourism village planning model in Padabeunghar Village involves various parties, both internal and external. Internal parties include the Padabeunghar Village government, local communities, and kompepar. Meanwhile, external parties such as the Kuningan Regency Government, the Youth, Sports, and Tourism Office (Dispopar), the Environment Agency, TNGC, the private sector as investors, and universities The community participation-based tourism village planning model can be described as follows:

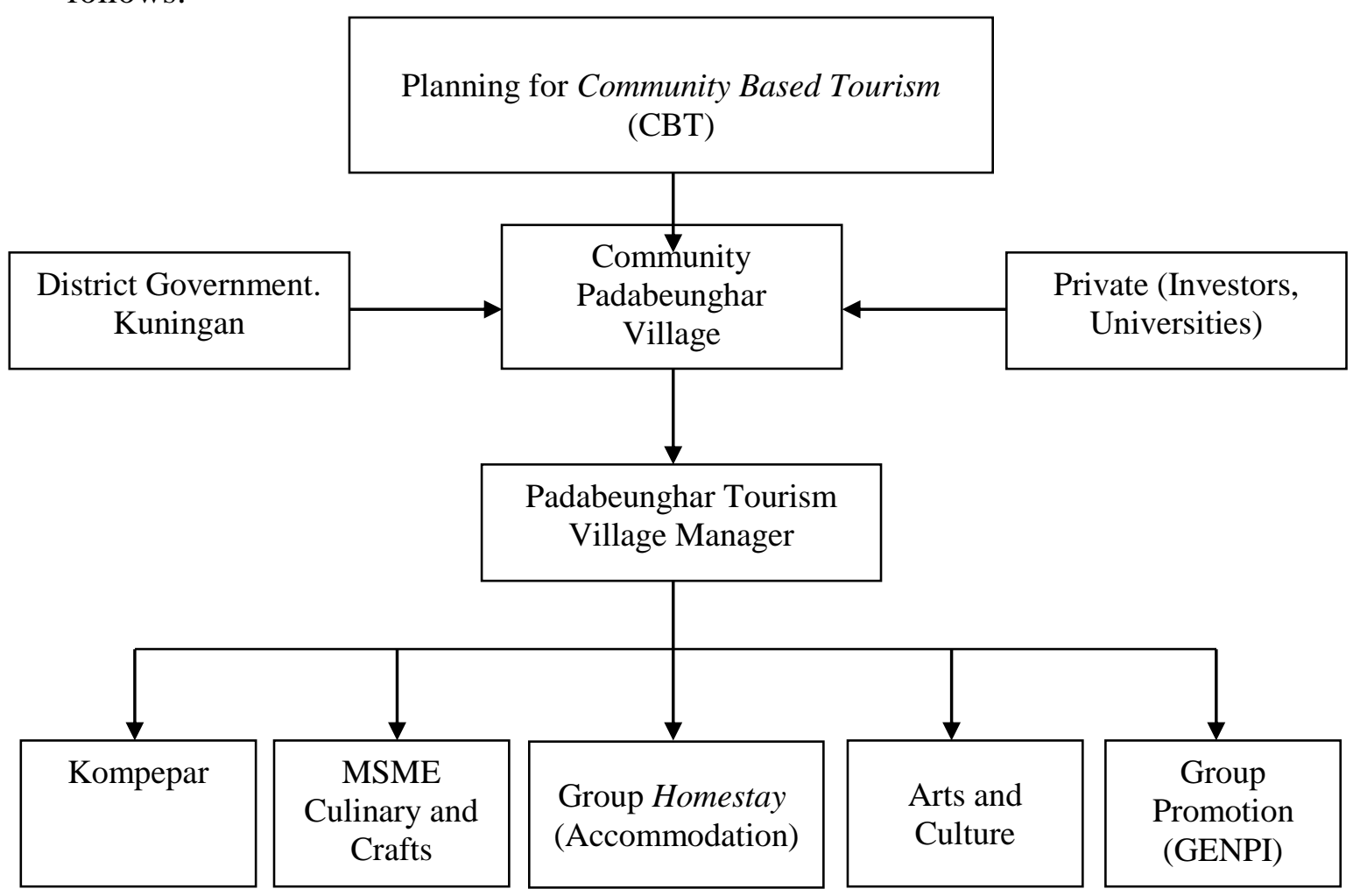

Figure 2. The Padabeunghar Tourism Village Planning Model

Source: Processed by Researchers (2019) 
In Figure 2, it can be seen that the Padabeunghar Tourism Village planning involves many stakeholders. Each party has different roles and responsibilities and can coordinate and cooperate with each other. The role of the Kuningan Regency Government, which consists of related agencies such as the Youth, Sports, and Tourism Office (Dispopar), is to assist the Padabeunghar Village government and carry out efforts to empower the Padabeunghar community in terms of training and certification of guides for tourism driving groups (kompepar), institutionally helping the formation of a compepar in collaboration with TNGC, conducting socialization for the implementation of Sapta Pesona, and making tourism information and promotions. The Environmental Service has made efforts to conserve the physical environment, empower tourism-aware groups in preserving the tourism environment, and improve village landscapes to support Sapta Pesona. The Department of Cooperatives and MSMEs empowers the community through training and fostering the quality of culinary products and handicrafts produced by MSMEs typical of Padabeunghar Village.

The roles of the Padabeunghar Village community in planning tourist villages include providing accommodation and guides, MSMEs in the village as providers of Padabeunghar culinary and handicrafts, cultural arts actors to attract tourists, and implementing Sapta Pesona. Kanom, Darmawan, and Nurhalimah (2020), the implementation of Sapta Pesona is one of the first steps in creating an atmosphere of environmentally friendly tourism destinations in order to realize a sustainable tourism destination.

The role of the private sector (investors) and universities is to make attractive tour packages at competitive prices, provide entrepreneurship training, train in language and hospitality skills, and develop business in tourist areas.

The role of the manager of the Padabeunghar Tourism Village is to manage, care for, protect, and preserve the tourist village, provide facilities to support the activities of the tourist village, grant and revoke placement permits, set requirements, and collect fees/retributions for the use of available facilities, all of which become the income of the tourism village manager, plan in the field of arts and culture as well as products produced by MSMEs, organize and develop institutions, direct the competence of tourism object managers, monitor and evaluate tourism activities for the development of sustainable tourism villages, make MoUs with the private sector so that $80 \%$ of the management tourism villages involve local communities and use local raw materials, encourage and mobilize communities to implement Sapta Pesona, and mobilize youth to be actively involved in the tourism sector.

\section{The Kuningan Regency Government's efforts in Community-Based Tourism Village Planning (CBT) in Padabeunghar Village, Pasawahan District, Tourism Village is a form of integration}

Between attractions, accommodation, and supporting facilities that are presented in a community life structure that integrates with applicable procedures and traditions. According to Law Number 10 of 2009 concerning tourism, it is explained that a tourist attraction is anything that has uniqueness, beauty, and value in the form of a diversity of natural, cultural, and man-made wealth that is the target or destination of tourist visits.

There are several criteria that must be met in order for a tourist attraction to be attractive to tourists, namely (Rizkianto and Topowijono, 2018):

a. Something to see, the tourist attraction must have a special attraction that can be seen by tourists. 
b. Something to do, a tourist attraction must be provided with several recreational facilities or amusements and places or rides that can be used by tourists for activities.

c. Something to buy, the tourist attraction must be available souvenir items (souvenirs) as well as local community crafts that tourists can buy as souvenirs.

d. Something to arrive is how tourists can reach a tourist attraction which includes accessibility, transportation and estimated time of arrival at the location of the tourist attraction.

e. Something to stay is how tourists will stay during a visit to the tourist attraction.

f. Something to learn is that there is something new experience that tourists get when visiting so as to increase the knowledge of tourists.

Based on the criteria of tourist attraction, Padabeunghar Village has the potential that can be used as an initial capital to build a tourist village. Padabeunghar Village has a vast, beautiful, and cool nature. There are irrigation rivers, bridges, lakes, and several tourist attractions such as Batu Luhur, Batu Sepur, Bukit Seribu Bintang, Cibujangga, Curug Ciguntur, and the Kuningan Botanical Gardens. In these tourist spots, there are many rides for activities, so that they have an attraction for tourists. Padabeunghar village also has various products that are processed from natural products such as herbs, melinjo chips, banana chips, and fans made of woven bamboo that can be used as souvenirs or souvenirs for tourists. However, Padabeunghar Village has not provided a home stay for tourists who want to spend the night. Another obstacle to realizing a tourist village in Padabeunghar is the narrow condition of the road leading to the village, which makes accessibility difficult because it can only be passed by small vehicles such as motorbikes and small cars, but buses cannot pass, meaning that large groups of tourists who will visit the Kuningan botanical garden are often rejected.

Based on the potential of Padabeunghar Village, the Kuningan Regency Government launched 25 (twenty-five) tourist villages and 100 tourism support villages (pinunjul), which will be realized gradually over the next five (five) years, as published in a letter The decision of the Kuningan Regent, which Padabeunghar Village is included in the program, So, according to the Department of Youth, Sports, and Tourism (Dispopar), Padabeunghar Village can choose to become a pinunjul village or a tourist village. If the choice is Pinunjul village, then determine the theme to be chosen, for example, agriculture, MSMEs (Micro, Small and Medium Enterprises), and others. Then the chosen field was developed, so that in the future, Padabeunghar Village will be known for a certain theme. However, if the choice is to become a tourist village, then to make it happen requires very long and complex stages.

According to Dispopar, several preparations that can be made to realize a tourist village include:

a. Preparation of Human Resources (HR)

Tourism is a service business, so the role of human resources (HR) is very large in determining the success of the business. The human resources needed to manage tourist villages are qualified human resources, such as friendly and polite people who have good communication skills, good language skills, creativity in creating products, and broad insight so that they can serve tourists well. The way that can be done is through education and training programs, so that human resources are formed that are ready to manage tourism in the village. 
Institutionally, a compepar (a tourism driving group) can be formed from the youth and youth groups. Currently, two compepars have been formed, but there is no coordination with the village, meaning that these compepars are run individually.

b. Preparation Financial

To realize a tourist village, resources are also needed in financial terms. So, in this case, there is synergy between the village, the Kuningan district government, TNGC, and other relevant agencies, as well as the private sector to support the budget needs for the formation of a tourist village in Padabeunghar. The village can allocate part of the village funds for the establishment of a tourist village.

c. Preparation of Infrastructure

Tourism can develop if it is supported by adequate infrastructure, including roads and transportation that facilitate access to tourist villages. The condition of the road to Padabeunghar Village is narrow and winding, so it can only be passed by motorbikes and small cars. If there is a group of tourists who will visit KRK by bus, their request will be rejected by the KRK manager because the road access is difficult for buses to pass. Therefore, infrastructure development is also a concern for the Kuningan Regency Government so that it can support the program for the formation of tourist villages and also Pinunjul villages. According to Dispopar, after the tourist village has been operating for one year, the Kuningan Regency Government will discuss infrastructure improvements.

d. Community Empowerment Program

One of the preparations made for the establishment of a tourist village in Padabeunghar is to prepare a community empowerment program to mobilize the potential that exists in the community, accompanied by the offices in Kuningan Regency and related agencies, such as the Youth, Sports, and Tourism Office. Dispopar), the Environment Service (DLH), Mount Ciremai National Park (TNGC), the Management of the Kuningan Botanical Gardens (KRK), the private sector (investors), as well as universities.

Empowerment programs that can be carried out include, for example, designing people's houses to be used as home stays for tourists, so the community will learn how to serve visitors with good hospitality and prepare parking spaces. Other empowerment programs can involve SMEs in Padabeunghar Village to produce products that can be used as souvenirs for tourists, both in the form of handicrafts (souvenirs) and food (culinary) typical of Padabeunghar Village. The empowerment of the Padabeunghar Village youth group can be done in collaboration with TNGC to form a compepar and then take part in the training and certification of guides held by Dispopar. Kompepar, in addition to being a tourism driver, is also a party that is concerned with nature conservation because the tourism that is managed is eco-tourism. Community empowerment in terms of nature conservation can work together with TNGC and the Environment Agency. In addition to kompepar, youths can also work with Dispopar in the field of promotion to become promotional ambassadors and with GENPI (Indonesian Charm Generation), which promotes tourism in Kuningan Regency.

Other forms of community empowerment can be done in collaboration with universities in the Cirebon and Kuningan areas, such as making home stay data, data guides, designing tour packages, skills training for MSMEs, and designing halal tourism. 
The village government and investors (private parties) can enter into cooperation $(\mathrm{MoU})$ in the formation of tourist villages, but in the MoU, investors are willing to involve local communities and use local raw materials by $80 \%$. This $\mathrm{MoU}$ will have an impact on improving the economy of the Padabeunghar Village community.

e. Implementation of Sapta Pesona Sapta Pesona,

Padabeunghar Village must implement certain conditions in order to attract tourists, including elements of security, cleanliness, coolness, beauty, hospitality, and memories. So the Kuningan Regency Government, through the Village Government, should aggressively carry out socialization of the implementation of Sapta Pesona in the community.

\section{CONCLUSION}

1. Padabeunghar Village has the potential to support tourist village planning. Several potentials to support the Padabeunghar Village plan as a tourist village are grouped into 3 (three) sectors, namely (1) natural potential, (2) institutional potential (local community) and (3) potential local wisdom products.

2. The Padabeunghar Tourism Village planning model involves various stakeholders, both internal and external, where each party has different roles and responsibilities and can coordinate with each other to create a sustainable tourism village.

3. The efforts of the Kuningan Regency government in planning community-based tourism are providing assistance and training to the village government and also the commcommunity, as well as changing the mindset of the community so that they want to develop. The role of the Kuningan Regency Government which consists of related agencies such as the Youth, Sports and Tourism Office (Dispopar) is to assist the Padabeunghar Village government and carry out efforts to empower the Padabeunghar community in terms of training and certification of guides for tourism driving groups (kompepar), institutionally helping the formation of a compepar in collaboration with TNGC, conducting socialization for the implementation of Sapta Pesona, and making tourism information and promotions. The Environment Agency carries out efforts to conserve the physical environment, empower tourism-aware groups in preserving the tourism environment, and improve village landscapes to support Sapta Pesona. The Department of Cooperatives and MSMEs empowers the community through training and fostering the quality of MSME culinary products and handicrafts typical of Padabeunghar Village.

\section{REFERENCES}

Damanik, Janianti dan Helmut F Weber, 2006, Perencanaan Ekowisata: Dari Teori ke aplikasi, Yogyakarta: Andi Offset.

Gunn, Clare A. and Var, Turgut, 2002, Tourism Planning; Basics, Concepts, Cases, Taylor \& Francis, USA

Inskeep Edward. (1991). Tourism Planning An Integrated and Sustainable Development Approach. New York: Van Nostrand Reinhold.

Kanom, K., Darmawan, R. N., \& Nurhalimah, N. (2020). Sosialisasi Penerapan Sapta

Pesona Dalam Perencanaan Dan Pengembangan Destinasi Pariwisata

Berkelanjutan Di Lider Desa Sumberarum Kecamatan Songgon Kabupaten Banyuwangi. Cendekia: Jurnal Pengabdian Masyarakat, 2(1), 24-32. 
Masruroh, R., \& Nurhayati, N. (2016, May). Strategi Pengembangan Pariwisata dalam Rangka Peningkatan Pendapatan Asli Daerah di Kabupaten Kuningan. In Prosiding Seminar Nasional IPTEK Terapan (SENIT) 2016 Pengembangan Sumber Daya Lokal Berbasis IPTEK (Vol. 1, No. 1).

Miles, B. Mathew dan Michael Huberman. 1992. Analisis Data Kualitatif Buku Sumber Tentang Metode-metode Baru. Jakarta: UIP.

Moleong, Lexy J. 2010. “MetodologiPenelitian Kualitatif”. Bandung: Remaja Rosdakarya.

Nuryanti, W., 1992, "Pariwisata Dalam Masyarakat Tradisional". Makalah pada Program Pelatihan Perencanaan dan Pengembangan Pariwisata. Jakarta.

Pearce, D.,1995, Tourism a Community Approach, 2nd: Harlow Longman.

Pendit, Nyoman S. 2003. "Ilmu Pariwisata 'Sebuah Pengantar Perdana”, Jakarta: Pradnya Paramita.

Peraturan Daerah Kabupaten Kuningan Nomor 2 Tahun 2013

Permanasari, I. (2010). Pengentasan Kemiskinan Melalui Pemberdayaan Masyarakat di Desa Wisata. Jurnal Kepariwisataan Indonesia, 5(1), 57-69.

Potensi Kepariwisataan Kabupaten Kuningan Tahun 2015.

Prasetya dan Ansar (2017). Pengembangan Desa Wisata Berbasis Community Based Tourism

Pada Kawasan Danau Ranau Lumbok Seminung Lampung Barat. Plano Madani, Volume 6 Nomor 1, 60 - 72.

Profil Pariwisata Kabupaten Kuningan Tahun 2015.

Rencana Kerja Pemerintah daerah Kabupaten Kuningan Tahun 2015.

Rizkianto dan Topowijono. (2018). Penerapan Konsep Community Based Tourism dalam Pengelolaan Daya Tarik Wisata Berkelanjutan (Studi pada Desa Wisata Bangun, Kecamatan Munjungan, Kabupaten Trenggalek). Jurnal Administrasi Bisnis (JAB). Vol 58, No. 2, 22-23

Sidiq dan Resnawaty. Pengembangan Desa Wisata Berbasis Partisipasi Masyarakat Lokal di Desa Wisata Linggarjati Kuningan, Jawa Barat. Prosiding KS: riset dan PKM, Vol: 4, No: 1 , hal $1-140$.

Sidiq, A. J., \& Resnawaty, R. (2017). Pengembangan desa wisata berbasis partisipasi masyarakat lokal di desa wisata Linggarjati Kuningan, Jawa Barat. Prosiding Penelitian dan Pengabdian kepada Masyarakat, 4(1), 38-44.

Sinclair, Thea. 1998. Tourism and Economic Development:a survey. Journal of Development Studies, 5, 1-51.

Suansri, P. 2003. Comunity Based Tourism Handbook. Bangkok, Thailand: Responsible Ecological Social Tours (REST) Project.

Sunaryo, Bambang. 2013. Kebijakan Pembangunan Destinasi Pariwisata Konsepdan Aplikasinya di Indonesia. Yogyakarta: Gava Media.

Suwantoro, Gamal. 2005. Dasar-dasar Pariwisata, Yogyakarta : Andi Offset.

Undang-undang RI Nomor 10 Tahun 2009 tentang Kepariwisataan.

www.kuningankab.go.id 